\title{
Does Corporate Social Responsibility Matter?
}

\author{
Janette Janette*, Nora Hendriyeni \\ Sekolah Tinggi Manajemen PPM \\ Jakarta, Indonesia \\ *lie.janette@gmail.com
}

\begin{abstract}
The purpose of this paper is to prove whether Corporate Social Responsibility affects the value of the company $\&$ to prove profitability as a moderating variable can strengthen the relationship of Corporate Social Responsibility with firm. CSR positively affect firm value and profitability (ROE) will strengthen the relationship between CSR and firm value. The study concentrates on CSR disclosure in the banking industries especially foreign exchange bank.
\end{abstract}

Keywords-corporate social responsibility, firm value, profitability, ROE, banking industries, foreign exchange bank

\section{INTRODUCTION}

The general purpose of the company is to gain profits from the business activities carried out. The company can use their profits for business process in the next period. Since 2017, public companies in Indonesia are required to pay attention to the social and environmental interests that helping the business of a company in a sustainable manner. The program is reported in the form of a sustainable financial report or commonly called a sustainability report.

In the international world sustainability report can be used as a form of company transparency regarding the impact of the business towards the environment and social, such as climate change and human rights. In addition to corporate transparency, sustainability reports also help companies make a better decision related to the company's social, environmental and economic aspects. One part that include inside the sustainability report is the disclosure of corporate social responsibility or commonly known as CSR.

The definition of CSR based on the EU Commission is the concept where companies integrate social and environmental issues in their business operations activities and company interactions with stakeholders [1]. The application of CSR in the company began in 1970, many experts began to realize the influence and important reasons why companies need to implement CSR. The importance of companies implementing CSR is also explained through the statement by Burke and Logsdon that in the short term CSR tends to incur costs but this will have an impact on corporate profits in the long run [2]. From the external side according to Howard R. Bowen in Melé (2008), CSR is a reflection of the responsibility of employers on the environment and social. The experts also suggest that one of the roles of accounting should be reporting the impact of the organization or company activities. In accordance with the information from Ballou and Heitger, CSR is one of the methods used by companies to present transparent reports, accurate and reliable data, as well as companies' performance [3]. The conclusion of the importance of companies implementing CSR is as a real disclosure of corporate responsibility due to the impact of business activities. In addition, CSR also supports the long-term sustainability of business activities and forms transparency to stakeholders.

The development of CSR in Indonesia began in 2007. In the beginning, UU No.40 - 2007 concerning Limited Companies used the term Social and Environmental Responsibility (TJSL) to regulate companies' regulation related to natural resources. After that further arrangements regarding the implementation mechanism of TJSL in Government Regulation Number 47 of 2012 Concerning Social and Environmental Responsibility of Limited Companies. During that time the implementation of TJSL was still carried out voluntarily except for companies whose activities are directly related to natural resources. Through Otoritas Jasa Keuangan (SAL POJK) Regulation, Number 51 / POJK.03 / 2017, the government requires Financial Services Institutions (LJK), issuers and public companies to implement sustainable finance. According to the National Centre for Sustainability Report (NCSR) sustainable financial reporting standards used in Indonesia follow the standards issued by the Global Reporting Initiative (GRI). Meanwhile, GRI also provide 91 point from GRI Sustainability Reporting guidelines - G4 to help companies disclosed their social and environment programs. This standard could be used as an international reference for any external parties.

Through this research, the author will examine about CSR effect in firm value. Firm value can be affected by a good reputation. According to the earlier research, a good reputation will affect the consumer preferences to purchase any products from the company. In this research, the author chose banking industry as a sample to conduct the research. Banking industry manage lot of funds that came from the third party, which means that banking industry should be responsible towards the fund (reliable) and giving back the benefit to the third party.

There are some studies on the influence of CSR in the banking industry. For example, it was carried out in several countries, such as Australia, Taiwan, Poland. McDonald and Rundle-Thiele research results [4]; McDonald and Lai [5]; Krasodomska states that CSR has a positive effect on the banking industry [6]. The disclosure of CSR will lead to trust and loyalty of consumers who invest their funds in the bank The same thing also happened in developed countries such as the UK, America and Germany which were explained through the results of Chambers and Day research [7], Jizi et al [8], Lock and Seele [9]. While for research in Indonesia the authors still find it difficult to find research that links CSR disclosure to the banking industry. 


\section{LITERATURE REVIEW}

\section{A. Signaling Theory}

Godfrey et al said that the signalling theory is a theory that emphasizes the importance of information released by the company to the company's external parties' decisions [10]. From the perspective of this theory, management voluntarily provides and provides information to investor that is useful in helping decision making. Management takes this role because they have a comparative advantage in the production and dissemination of information.

Signalling theory arises from the study of economic information in conditions where internal and external parties have information asymmetry when facing market reactions [11]. Assuming that the company is rational, external parties look for signals to find out which companies will provide benefits or vice versa. Signals given by companies can be in the form of actions or strategies.

A similar opinion from Stiglitz states that signalling theory discusses information asymmetry between two parties where the information is related to the quality and objectives of the company [12]. In his statement, Stiglitz highlighted two types where information asymmetry often occurs. First, information related to company quality. This becomes important when one party (stakeholders) does not fully know the character of the other party (company management). Second, information relating to the company's goals or intentions. This happens when one party is concerned about the habits or purpose of the actions taken by the company.

The benefit of signalling theory is to describe the behaviour of two parties (individuals or organizations) who have different information access. The sender of information must think about how to communicate or how to signal the information. On the other hand, the recipient of the information must know how to interpret the signal [13].

Signalling theory states that every information published by a company becomes one of the reasons or determinants of the action taken by the recipient of the information [14]. Certain signals issued by companies can provide beneficial benefits for both the giver of information and the recipient of information [15].

Drawing conclusions from the above explanation, every company will always issue a signal that is expressed in a certain way to the market. This signal aims to provide guidance or a general picture of the market where the information relates to the purpose or condition of the company in the coming period. As a receiver of signals or information, market reactions are determined according to interpretations obtained from the signals given by the company.

\section{B. Stakeholder Theory}

According to Donaldson and Preston, stakeholder theory is grouped into three aspects: normative, instrumental and descriptive [16]. In normative aspect, stakeholder theory is used to interpret corporate functions, including identification of moral or philosophical guidelines created for corporate operations and management. In normative use, the correspondence between theory and facts from company activity is not a significant problem. Instead, a normative theory seeks to interpret functions and offer guidance to companies based on some moral principles or underlying philosophies. As an instrument, stakeholder theory is used to identify connections or lack of connections between management and stakeholders related to profit and corporate growth. Based on descriptive aspects, stakeholder theory reflects and explains the state of the company's relationships in the past, present and future.

Supporting a similar statement, Jones and Wicks says that stakeholder theory focuses on business, community or social relations and business ethics [17]. Stakeholder theory pays attention to the nature of the relationship between the processes and outcomes of a company on the environment and social. Stakeholder theory also focuses on managerial decisions making.

The company has relationships with stakeholder groups that influence and are influenced by company decisions. This statement is reinforced in Freeman et al that the basic idea to create value for stakeholders is very much started from the existence of a business relationship between the company and stakeholders [18]. The word business can be understood as a set of relationships between groups that have an interest in an activity. Business is about how consumers, suppliers, employees, shareholders, the community and management interact and create value. Understanding business means understanding how the relationship works.

In conclusion, stakeholder theory has evolved to address issues such as understanding and managing a business that places importance on creating value from business activities that occur; formulate ideas about ethical issues, responsibility and sustainability (sustainability); understand what must be taught to management about what is needed to be successful in the business world. By focusing on the basic theories of stakeholders we can understand that through CSR programs run by the company aims to provide environmental and social benefits that indirectly support a company's business activities.

\section{Corporate Social Responsibility}

Based on the statement of the EU Commission in Crowther and Aras, CSR is a concept where companies integrate social and environmental care in their business operations activities and company interactions with stakeholders [1]. Explaining a similar definition Moir says CSR is a continuation of commitment by companies to behave ethically and contribute to economic development [19]

Furthermore, it is said that CSR is a concept that has become dominant in business reporting. Each company has a policy regarding CSR and produces an annual report that contains details of CSR activities. The broad definition of CSR is corporate social responsibility related to the relationship between companies, governments and citizens. More specifically explained that the citizens in question are the local community where the company is located and operates [1]

Internationally CSR began in 1970. Many experts began to realize the need for the application of CSR. From the internal side of the company, Burke and Logsdon states that, in the long run CSR will provide economic benefits for the company [2]. Furthermore, researchers identified several strategies that can be used for CSR program planning that have an impact on company profits. The intended strategy is centrality, which explains that the CSR program undertaken has the same 
objectives and mission as the company; specificity describes how much the ability of CSR programs can generate profits for the company; activity aimed at making plans for the composition of CSR programs that follow social trends; Visibility explains that CSR programs must be observable and known by stakeholders. Thus, CSR programs are important because the company has expectations that when the company's value is good in the market, it will have an impact on the company's economic profit.

The treatment and disclosure of CSR by companies also provide benefits for the external side of the company. Melé states that in addition to the interest to seek profits, companies also have responsibility for social and environmental problems that are created along with business travel in the company [20]. In other words, if the company improves its performance or CSR program, it means the company is trying to show its form of responsibility in minimizing negative impacts on the environment. It can be concluded that the implementation of CSR in companies is a form of corporate responsibility for the impact of its business activities and CSR can support the sustainability of business activities in the long run.

The experts also suggest that one of the roles of accounting science should be to report on the impact of the activities of the organization or company. This is in line with one of the accounting frameworks known as triple bottom line. The triple bottom line consists of economic, social and environmental aspects. From this framework the company is asked to continue to assume that economic aspects such as profit are as important as social and environmental aspects. The triple bottom line concept explains that companies have responsibilities towards stakeholders, and not just shareholders. The intended stakeholders are any parties, both internal and external, who are directly and indirectly affected by the activities of a company.

In Indonesia, CSR disclosure or better known as the implementation of Environmental Social Responsibility (TJSL) began to develop in 2007. The term TJSL is used in Law Number 40 of 2007 concerning Limited Liability Companies that regulate obligations for companies relating to natural resources. Furthermore, in Government Regulation Number 47 of 2012 concerning Limited Liability Company TJSL, arrangements are made regarding the mechanism for implementing TJSL. This regulation highlights that every company as a legal subject has social and environmental responsibility. During that time the implementation of TJSL was done voluntarily. Except for companies whose activities are related to natural resources. Until finally in 2017, making and publishing sustainability reports becomes one of the obligations for Financial Services Institutions (LJK), issuers and public companies. This statement is written in a copy of the Financial Services Authority Regulation (SAL POJK) Number 51 / POJK.03 / 2017. The financial reporting standards used in Indonesia follow the standards issued by the Global Reporting Initiative (GRI).

The GRI sustainability report standard designed to be used by companies to make reports on the impact of their business activities on the economy, social and environment. The GRI Reporting Principles are the basis for producing quality sustainability reports. This basis is divided into two groups, namely principles for defining report content and principles for defining report quality. The principles for defining report content help companies to decide what content should be included in the report. In this section there are points about sustainability context. This point explains that the report made must present organizational performance in the broader context of sustainability. Some standards issued by GRI in expressing sustainability context are that reporting organizations present an understanding of sustainability reports and provide objective information, organizations present their performance in communicating impacts and contributions in accordance with geographical contexts, and organizations describing how economic, social and environmental topics relate to long-term strategies, organizational risks and objectives. In addition, GRI also issued guidelines for disclosing CSR programs that have been carried out by organizations or companies. The guideline is the GRI Sustainability Reporting Guidelines - G4, which was last published in May 2013. This guideline has 91 standard disclosure points. This guideline also helps provide international references for all parties interested in the disclosure of a governance approach and environmental, social and economic performance and the organizational impact of a company.

In accordance with GRI's statement, CSR disclosure can give stakeholders an idea of the true value of the company through the program being implemented. This statement is supported by the results of Michelon's research, which says that CSR disclosure is a form of communication with stakeholders that provides information on company activities and legitimizes corporate behaviour [21]. CSR disclosure shows how organizations are influenced and affect the environment. The same statement is found in Melé, that the company's social performance is strived to be equal or in accordance with the expectations of external parties that are in contact with the company's business activities [20]. Ultimately, this will lead to the company's reputation in the market. To get a good reputation, the company must get a positive response from stakeholders about the CSR program disclosed by the company [22].

\section{Firm Value}

The existence of certain activities in a company has an impact on the value of the company. Activities that occur include political activity, regulatory changes, information disclosure and others. When viewed from an internal perspective, every decision made by a public company is disclosed to the public through information disclosure to the company's financial statements and annual reports. Investors and other external parties who see or get information from the company have a different perspective and reaction to the information. If the information is considered profitable, then investors have high expectations of the company. This is what then influences the company's value in the market [23].

Companies that have a performance that is considered good usually have a high value in the market. One common method is to look at the company's stock price on the stock exchange [24]. From a financial perspective, good performance can be assessed through financial ratio information provided by the company. However, in accordance with regulations in Indonesia that began in 2017, public companies are not only required both financially but also through corporate environmental and social responsibility. With the disclosure of corporate responsibility, investors and stakeholders can assess the other side that determines the company's value in the eyes of the market [22]. Because through the disclosure of these 
responsibilities, the company seeks to increase market share which has an impact on customer loyalty and affects company profits. In addition, this method can be used as an advantage and value added company compared to competitors [25].

\section{SURVEY METHOD AND RESULTS}

\section{A. The Purpose of Research and Method Used}

The purpose of this research was to prove whether Corporate Social Responsibility affects the firm value \& to prove profitability (as a moderating variable) strengthen the relationship between Corporate Social Responsibility and firm value.

This research was conducted using secondary data. Secondary data in this study are in the form of annual reports and financial reports obtained through Indonesia Stock Exchange (www.idx.co.id) and through the websites of each company. The period used in this study is 5 years, from 2014 2018. The Research sample comprised 13 foreign exchange bank listed in Indonesia Stock exchange.

\section{B. Hypothesis Development}

Corporate Social Responsibility is a concept or program where companies integrate social and environmental care in their business operations and company interactions with stakeholders. From the results of Michelon research, companies that have good financial performance where the company is facing pressure from the public will usually use sustainability disclosure [21]. Which is one of them is CSR disclosure as a communication tool that legitimizes the company's activities to stakeholders and forms of responsibility to stakeholders. CSR programs designed to create strategic advantages for company. It's called strategic when the CSR program provides benefits related to the company's substantial business, specifically by supporting the company's core business activities. This can help the company's effectiveness in achieving its goals both in financial and social value [2].

In McDonald and Lai study, conducted in the banking industry in Taiwan, CSR disclosure has an effect on customer's attitude, which directly determines positive customer behaviour [5]. From this, the company management can take an advantage to attract more customers, which in turn has an impact on strengthening the company's financial performance and corporate value in the market.

The same thing happens in the banking industry in America, CSR disclosure provides information to investors that have an impact on investors' assessments or assessments of the company [8]. The above explanation forms the basis for the following hypothesis:

\section{H1: CSR disclosure has a positive effect on firm value.}

In the research of Cochran and Wood it is stated that the basic idea to find out investor returns (the rate of return for investors) is: the rate of return must be measured from the perspective of shareholders or investors [26]. Therefore, to determine the level of return, the company must have indicators related to the company's financial performance that can be used as information for investors.

One indicator that can measure the rate of return for investors is profitability. This is because profitability is an indicator that directly related to a company's financial capability, so it is often used as a special point to evaluate the company's financial performance [27]. There are severa comparisons that can be used to measure the profitability of a company, including the ratio between net income and total assets commonly known as return on assets (ROA), the ratio between net income and equity or commonly called return on equity (ROE) and others. In this study authors use ROE as a tool to measure the profitability of the company.

Tsoutsoura research results states that companies with high and strong profitability will be more free to invest their resources in social performance and environmental issues [28]. With a high level of profitability, the company can allocate its resources to CSR programs that will provide benefits in the long run. These advantages include, the company can improve its image in the market and maintain investor confidence towards the fund that has been invested in the company. This is because the existence of CSR program provides transparency on the allocation of resources from investors used by the company. This is also in line with the author's choice to use $\mathrm{ROE}$ as a tool to measure the profitability of the company, because ROE measures the return on funds obtained and entrusted by investors to the company. The above explanation forms the basis for the following hypothesis:

$\mathrm{H}$ 2: A high level of profitability (ROE) can strengthen the relationship of CSR with firm value.

\section{Verification of the Hypothesis}

TABLE I. H1: CSR DISCLOSURE HAS A POSITIVE EFFECT ON FIRM VALUE

\begin{tabular}{|c|l|l|l|l|l|c|}
\hline \multicolumn{2}{|c|}{ Model } & $\begin{array}{l}\text { Sum of } \\
\text { Square }\end{array}$ & df & $\begin{array}{c}\text { Mean } \\
\text { square }\end{array}$ & F & Sig. \\
\hline 1 & Regression & 0.020 & 1 & 0.020 & 13.214 & $0.001^{\text {b }}$ \\
\hline & Residual & 0.096 & 63 & 0.002 & & \\
\hline & Total & 0.117 & 64 & & & \\
\hline
\end{tabular}

Based on testing that has been done in table 1 , there are results showing that the significance value is $0.001 \quad(<0.05)$ which states that $\mathrm{H} 0$ is rejected and $\mathrm{H} 1$ is accepted. So it can be concluded that the CSR disclosure index has a positive effect on firm value (PER), especially in companies in the banking sector. This means that the greater the disclosure of CSR of a company, the greater the value of the company.

The results of this study support the opinion of McDonald and Rundle-Thiele [4], McDonald and Lai [5] and Mocan et al [29] who conducted a similar study in the banking industry in developed and developing countries, stated that reporting CSR programs conducted by the company would have a positive impact on customer loyalty, company reputation, company communication with stakeholders, which in turn would have an impact on the company's value in market. Therefore, it can be concluded that the banking sector in Indonesia is also doing the same thing, that the disclosure of CSR will have a positive effect on company value.

One of the factors driving CSR disclosure in Indonesia is the emergence of regulations from the OJK which says that starting in 2017, all public companies are required to report on environmental social responsibility (TJSL). It aims to increase transparency and report on corporate responsibility towards stakeholders. In the end this disclosure provides its own benefits for the company. 
TABLE II. H2: A HIGH LEVEL OF PROFITABILITY (ROE) CAN STRENGTHEN THE RELATIONSHIP OF CSR WITH FIRM VALUE

\begin{tabular}{|c|l|l|l|l|c|c|}
\hline \multicolumn{2}{|l|}{ Model } & $\begin{array}{l}\text { Sum of } \\
\text { Square }\end{array}$ & df & $\begin{array}{c}\text { Mean } \\
\text { square }\end{array}$ & F & Sig. \\
\hline 1 & Regression & 0.038 & 2 & 0.013 & 10.015 & $0.000^{\mathrm{b}}$ \\
\hline & Residual & 0.078 & 61 & 0.001 & & \\
\hline & Total & 0.117 & 64 & & & \\
\hline
\end{tabular}

Based on tests that have been done in table 2, there are results that indicate that the significance value is $0.000(<0.05)$ and the increasing coefficient of determination indicates that $\mathrm{H} 0$ is rejected and $\mathrm{H} 1$ is accepted. This means that ROE can be a moderating variable that strengthens the relationship between CSR and corporate value.

Although the authors still find it difficult to find previous studies that use ROE as a moderating variable in the banking sector, in the Cochran and Wood study it is stated that the basic idea to find out investor returns is that the rate of return must be measured from the perspective of the holder shares or investors [26]. Therefore, to determine the level of return the company must have indicators related to the company's financial performance that can be used as information for investors. In addition, ROE (profitability) is a financial ratio that is used to measure the rate of return for investors. This is because profitability is one indicator that is directly related to a company's financial capability, so it is often used as a special point to evaluate the company's financial performance [27]. Meanwhile, in the opinion of Tsoutsoura companies with high and strong profitability will be more flexible to invest their resources in social performance and environmental issues [28]. In other words, companies will be free to do the CSR program and report on CSR activities.

The above description is in line with the results of the study, which states that ROE is able to be a moderating variable between CSR and firm value. With a high ROE level, companies will be more flexible to allocate their resources into CSR programs and for the long run CSR will provide its own benefits for the company.

\section{CONCLUSION AND FUTURE AIM}

Based on the results of research that has been done, it was concluded that CSR has a positive influence on firm value and ROE which used as a moderating variable in this study being able to be a moderator in the relationship of CSR with firm value.

\section{RESEARCH LIMITATION}

From the research that has been done, the author realizes that there are limitations that need to be considered again in subsequent studies. Limitations in this study are:

- The subjectivity factor in measuring CSR index in each company

- The author only uses samples from the banking industry, so this research cannot represent other sectors

- Only few companies disclose their CSR program reports in accordance with GRI G-4 standards

Furthermore, the next research can expand this study by comparing several sectors to see whether this model can be generalized.

\section{REFERENCES}

[1] D. Crowther and G. Aras, Corporate Social Responsibility. Ventus Publishing, 2008.

[2] L. Burke and J.M. Logsdon, "How Corporate Social Responsibility Pays Off," Long Range Planning, vol. 29, no. 4, pp. 495-502, 1996.

[3] B. Ballou and D.L. Heitger, "The Rise of Corporate Sustainability Reporting : A Rapidly-Growing Assurance Opportunity The Rise of Corporate Sustainability Reporting: A Rapidly-Growing Assurance Opportunity," Journal of Accountancy, vol. 202, no. 6, pp. 65-74, 2005.

[4] L.M. McDonald and S. Rundle-Thiele, "Corporate social responsibility and bank customer satisfaction: A research agenda," International Journal of Bank Marketing, vol. 26, no. 3, pp. 170-182, 2008.

[5] L.M. McDonald and C.H. Lai, "Impact of corporate social responsibility initiatives on Taiwanese banking customers," International Journal of Bank Marketing, vol. 29, no. 1, pp. 50-63, 2011

[6] J. Krasodomska, "CSR disclosures in the banking industry, Empirical evidence from Poland," Social Responsibility Journal, vol. 11, no. 3, pp. 406-423, 2015.

[7] C. Chambers and R. Day, "The banking sector and CSR: An unholy alliance?" Financial Regulation International, vol. 12, no. 9, pp. 13-20, 2009

[8] M.I. Jizi, A. Salama, R. Dixon, and R. Stratling, "Corporate Governance and Corporate Social Responsibility Disclosure: Evidence from the US Banking Sector," Journal of Business Ethics, vol. 125, no. 4, pp. 601615, 2013.

[9] I. Lock and P. Seele, "Analyzing sector-specific CSR reporting: Social and environmental disclosure to investors in the chemicals and banking and insurance industry," Corporate Social Responsibility and Environmental Management, vol. 22, no. 2, pp. 113-128, 2015.

[10] J. Godfrey, A. Hodgson, A. Tarca, J. Hamilton, and S. Holmes, Accounting Theory. Australia: Wiley, 2010.

[11] W. Boulding and A. Kirmani, "A Consumer-Side Experimental Examination of Signaling Theory: Do Consumers Perceive Warranties as Signals of Quality?" Journal of Consumer Research, vol. 20, no. 1, pp. 111, 1993.

[12] J.E. Stiglitz, "The contributions of the economics of information to twentieth century economics," Quarterly Journal of Economics, pp. 1441-1478, 2000

[13] B.L. Connelly, S.T. Certo, R.D. Ireland, and C.R. Reutzel, "Signaling 42 theory: A review and assessment," Journal of Management, vol. 37, no. 1, pp. 39-67, 2011.

[14] R. Karasek and P. Bryant, "Innovation in large corporations: A development of the rudimentary theory of effectuation," Academy of Strategic Management Journal, vol. 11, no. 1, pp. 91-100, 2012.

[15] B.R. Bliege and E.A. Smith, "Signaling Theory, Strategic Interaction, and Symbolic Capital," Current Anthropology, vol. 46, no. 2, pp 221-248, 2005.

[16] T. Donaldson and L.E. Preston, "Donaldson ym._The stakeholder theory of the corporation," Academy of Management Review, vol. 20, no. 1, pp. 65-91, 1995.

[17] T.M. Jones and A.C. Wicks, "Convergent Stakeholder Theory," Academy of Management Review, vol. 24, no. 2, pp. 206-221, 1999.

[18] R.E. Freeman, S.J. Harrison, A.C. Wicks, B. Parmar, and S. De Colle, Stakeholder Theory. Cambridge University Press, 2010.

[19] L. Moir, "What do We Mean by Corporate Social Responsibility ? Corporate Governance," The International Journal of Business in Society, vol. 1, no. 2, 2001.

[20] A. Crane, A. McWilliams, D. Matten, J. Moon, and D.S. Siegel, The Oxford handbook of corporate social responsibility. Oxford University Press on Demand, 2008

[21] G. Michelon, "Sustainability disclosure and reputation: A comparative study," Corporate Reputation Review, vol. 14, no. 2, pp. 79-96, 2011.

[22] E. Colleoni, "CSR communication strategies for organizational legitimacy in social media," Corporate Communications, vol. 18, no. 2, pp. 228-248, 2013.

[23] W.G. Blacconiere and D.M. Patten, "Environmental disclosures, regulatory costs, and changes in firm value," Journal of Accounting and Economics, vol. 18, no. 3, pp. 357-377, 1994. 
[24] E.F. Fama and K.R. French, "Taxes, financing decisions, and firm value," The journal of Finance, vol. 53, no. 3, pp. 819-843, 1998.

[25] M.E. Porter and M.R. Kramer, "Harvard Business Review The Link Between Competitive Advantage and Corporate Social Responsibility,' Harvard Business Review, pp. 78-93, 2006.

[26] P.L. Cochran and R.A. Wood, "Corporate social responsibility and financial performance nexus," Journal of Global Responsibility, vol. 9 , no. 3, pp. 301-328, 1984.
[27] S.W. Joh, "Corporate governance and firm profitability: Evidence from Korea before the economic crisis," Journal of Financial Economics, vol. 68, no. 2, pp. 287-322, 2003.

[28] A. Tsoutsoura, Working Paper Series Title Corporate Social Responsibility and Financial Performance [Online]. Retrieved from: https://escholarship.org/uc/item/111799p2, 2004.

[29] M. Mocan, S. Rus, A. Draghici, L. Ivascu, and A. Turi, "Impact of Corporate Social Responsibility Practices on the Banking Industry in Romania,” Procedia Economics and Finance, pp. 712-716, 2015 